\title{
Metabolic Effects of Abomasal L-Carnitine Infusion and Feed Restriction in Lactating Holstein Cows
}

\author{
D. B. Carlson, ${ }^{\star 2}$ N. B. Litherland, ${ }^{\star 3}$ H. M. Dann, ${ }^{* 4}$ J. C. Woodworth, $†$ and J. K. Drackley ${ }^{\star 5}$ \\ ${ }^{*}$ Department of Animal Sciences, University of Illinois, Urbana 61801 \\ †Lonza, Inc., Allendale, NJ 07401
}

\begin{abstract}
L-Carnitine is required for mitochondrial fatty acid oxidation, but the effects of carnitine supplementation on nutrient metabolism during dry matter intake depression have not been determined in dairy cows. Studies in other species have revealed responses to L-carnitine that may be of specific benefit to dairy cows during the periparturient period. Eight lactating Holstein cows $(132 \pm 36 \mathrm{~d}$ in milk) were used in a replicated $4 \times 4$ Latin square experiment with 14 -d periods. Treatments were factorial combinations of abomasal infusion of either water or L-carnitine $(20 \mathrm{~g} / \mathrm{d}$; d 5 to 14$)$ and either ad libitum or restricted intake (50\% of previous 5-d dry matter intake; d 10 to 14) of a balanced lactation diet. Liver and muscle biopsies were obtained on d 14 of each period. Feed restriction induced negative balances of energy and metabolizable protein. In feed-restricted cows, carnitine infusion increased 3.5\% fat-corrected milk yield compared with those infused with water. Total carnitine concentration in liver was increased in feed-restricted cows infused with carnitine but not in feed-restricted cows infused with water. Carnitine infusion stimulated in vitro oxidation of $\left[1-{ }^{14} \mathrm{C}\right]$ palmitate to acid-soluble products and decreased the proportion of $\left[1-{ }^{14} \mathrm{C}\right]$ palmitate that was converted to esterified products by liver slices. Feed-restricted cows infused with carnitine had lower liver total lipid concentration and tended to have decreased triglyceride accumulation compared with feed-restricted cows infused with water. Plasma nonesterified fatty acid concentration was not altered by carnitine infusion but was increased by feed restriction; serum $\beta$-hydroxybutyric acid was increased
\end{abstract}

Received May 18, 2006

Accepted July 1, 2006.

${ }^{1}$ Supported by Lonza, Inc., Allendale, NJ.

${ }^{2}$ D. B. Carlson was supported by a Jonathan Baldwin Turner Graduate Fellowship, College of Agricultural, Consumer and Environmental Sciences, University of Illinois.

${ }^{3}$ Present address: Animal Science Department, Oklahoma State University, Stillwater 74078.

${ }^{4}$ Present address: William H. Miner Agricultural Research Institute, Chazy, NY 12921.

${ }^{5}$ Corresponding author: drackley@uiuc.edu by carnitine infusion in feed-restricted cows. In cows fed for ad libitum intake, carnitine infusion affected $\beta$ hydroxybutyric acid, insulin, and urea $\mathrm{N}$ in serum, liver glycogen concentration, and in vitro alanine oxidation by liver slices, suggesting that hepatic and peripheral nutrient metabolism was influenced. L-Carnitine infusion effectively decreased liver lipid accumulation during feed restriction as a result of greater capacity for hepatic fatty acid oxidation. Further research examining dietary supplementation of L-carnitine during the periparturient period is warranted.

Key words: L-carnitine, hepatic metabolism, fatty liver, dairy cow

\section{INTRODUCTION}

The periparturient period is a critical time in the lactation cycle because the cow is prone to numerous metabolic disorders and infectious diseases. The transition from gestation to lactation generally is accompanied by decreased DMI, negative energy balance, and extensive mobilization of body tissue stores of nutrients (Drackley, 1999). Failure to adapt to negative energy balance results in metabolic disorders such as fatty liver and ketosis (Herdt, 2000). Fatty liver occurs when excessive amounts of NEFA are esterified to triglycerides (TG) as a result of suboptimal hepatic fatty acid oxidation and limited TG export. Fatty liver is associated with an increased risk of ketosis, displaced abomasum, metritis, immune suppression, and decreased reproductive performance (Bobe et al., 2004). Researchers have attempted to alter hepatic metabolism and prevent fatty liver by reducing NEFA mobilization from adipose tissue, by enhancing hepatic fatty acid oxidation, or by increasing TG export from the liver through manipulation of pre or postpartum nutrition (Bobe et al., 2004). However, a definitive approach to prevention of fatty liver remains to be elucidated.

Carnitine is an essential substrate for carnitine palmitoyltransferase-I (CPT-I; EC 2.3.1.21), a mitochondrial enzyme that condenses carnitine with fatty acylCoA to form acylcarnitine. The carnitine-acylcarnitine system is required for mitochondrial oxidation because the inner mitochondrial membrane is impermeable to 
long-chain fatty acids (McGarry and Brown, 1997). Additional functions of carnitine include modulating the ratio of acetyl-CoA:CoA, modulating the toxic effects of poorly metabolized acyl groups, shuttling activated medium- and short-chain organic acids from peroxisomes to mitochondria, and altering branched-chain amino acid metabolism (Rebouche and Seim, 1998; Owen et al., 2001). Carnitine is synthesized endogenously from Lys (carbon backbone) and Met (methyl group donor); however, these AA are not directly converted to carnitine but are required for synthesis of the endogenous carnitine precursor trimethyllysine. The rate of protein turnover and the trimethyllysine content in proteins are the main factors determining the rate of endogenous carnitine synthesis (see review by Vaz and Wanders, 2002). Despite increased hepatic carnitine concentration around calving (Grum et al., 1996), insufficient endogenous carnitine synthesis might contribute to fatty liver development.

The influence of supplemental carnitine on nutrient metabolism, milk production, and milk composition in lactating cows fed for ad libitum DMI has been investigated previously (LaCount et al., 1995, 1996a,b). In vitro studies have demonstrated that supplemental carnitine may alter in vivo hepatic fatty acid metabolism; carnitine addition to incubation media increased palmitate oxidation by bovine liver slices (Jesse et al., 1986b; Drackley et al., 1991a), bovine hepatocytes (Knapp, 1990), and sheep hepatocytes (Lomax et al., 1983). Recent research in dairy cows has demonstrated that hepatic CPT-I activity (Dann and Drackley, 2005) and mRNA abundance (Loor et al., 2005) were markedly higher at $\mathrm{d} 1$ and 14 after calving compared with prepartum values; however, sensitivity of CPT-I to malonylCoA inhibition did not change (Dann and Drackley, 2005). Higher CPT-I mRNA abundance was positively correlated with liver TG concentration (Loor et al., 2005), suggesting that CPT-I activity was not adequately increased to prevent liver TG accumulation despite increased mRNA. In light of increased CPT-I activity, greater CPT-I mRNA abundance, and elevated serum NEFA around calving, increasing hepatic carnitine availability might stimulate mitochondrial fatty acid oxidation in the liver.

Our hypothesis was that postruminal carnitine infusion in lactating dairy cows would increase hepatic carnitine concentration, stimulate fatty acid oxidation, and decrease liver TG accumulation during DMI depression. Feed restriction was utilized to induce negative energy balance and adipose tissue lipolysis characteristic of the periparturient period. The objective was to determine the effects of postruminal carnitine infusion and amount of feed intake on in vitro hepatic metabolism, in vivo liver composition, blood metabolite concen- trations, and production responses of lactating Holstein cows.

\section{MATERIALS AND METHODS}

\section{Cows, Diets, and Treatments}

All experimental procedures were conducted according to protocols approved by the University of Illinois Institutional Animal Care and Use Committee. Eight lactating, multiparous Holstein cows fitted with ruminal cannulas (10.2-cm o.d.; Bar Diamond, Parma, ID) were stratified by DIM and assigned to 1 of 2 blocks (block $1=162 \pm 20$ DIM; block $2=101 \pm 16$ DIM) in a replicated $4 \times 4$ Latin square with 14 -d periods. Cows within each block were assigned randomly to 1 of 4 treatments in a $2 \times 2$ factorial arrangement: 1 ) water infusion, ad libitum DMI (WA), 2) water infusion, restricted DMI (WR), 3) carnitine infusion, ad libitum DMI (CA), and 4) carnitine infusion, restricted DMI (CR).

Abomasal infusion was accomplished by placing an apparatus into the abomasum by way of the ruminal cannula as described by Litherland et al. (2005). The placement of the infusion apparatus was confirmed daily by palpation of the reticulo-omasal orifice to ensure postruminal delivery of infusion treatments. Cows were infused every $6 \mathrm{~h}$ at $0600,1200,1800$, and 2400 h. During each 14-d period, d 1 to 4 served as a washout period in which all cows were infused with water to reduce carryover effects of previous treatments. From d 5 to 14, cows were infused with either water or Lcarnitine [L-(3-carboxy-2-hydroxypropyl)trimethyl-ammonium hydroxide; inner salt, $\geq 97 \%$ purity; Lonza, Inc., Allendale, NJ]. Carnitine infusate was prepared daily for each cow by dissolving L-carnitine $(20 \mathrm{~g})$ in warm tap water $(400 \mathrm{~mL})$; the solution was then refrigerated at $4^{\circ} \mathrm{C}$. At each 6 -h interval, a syringe was used to flush the infusion line with tap water $(100 \mathrm{~mL})$ followed by infusion of either carnitine solution or tap water (100 $\mathrm{mL})$. The tubing then was flushed with tap water (100 $\mathrm{mL}$ ) again to prevent the treatment from remaining in the infusion line. Each carnitine infusion delivered $5 \mathrm{~g}$ of L-carnitine postruminally, resulting in a daily dose of $20 \mathrm{~g}$.

Beginning on $\mathrm{d} 10$ of each period, cows assigned to WR and CR treatments were fed $50 \%$ of the previous 5-d average DMI to stimulate lipid mobilization from adipose tissue, whereas the WA and CA treatments were allowed to continue ad libitum access to feed. The DMI during $d 1$ to 4 of each period was not used in calculations of the amount of feed to be offered during feed restriction to allow for recovery from tissue biopsies and previous feed restriction. All cows were fed a lacta- 
Table 1. Ingredient and nutrient composition (DM basis) of the experimental diet

\begin{tabular}{lc}
\hline & \% of \\
Ingredient & dietary DM \\
\hline Corn silage & 28.13 \\
Alfalfa silage & 20.10 \\
Cottonseed & 9.65 \\
Corn, ground & 26.05 \\
Soybean meal, 48\% & 5.14 \\
Soybean meal, expeller ${ }^{1}$ & 6.03 \\
Soybean hulls & 1.45 \\
Limestone & 1.41 \\
Sodium bicarbonate & 0.96 \\
Dicalcium phosphate & 0.52 \\
Magnesium oxide & 0.12 \\
Salt, white & 0.20 \\
Mineral and vitamin mix ${ }^{2}$ & 0.20 \\
Vitamin $\mathrm{E}^{3}$ & 0.04 \\
Nutrient content & \\
CP & \\
ADF & 17.3 \\
NDF & 20.4 \\
NE, Mcal/kg & 32.1 \\
Ca & 1.73 \\
Mg & 1.30 \\
K & 0.49 \\
Na & 0.30 \\
S & 1.45 \\
\hline
\end{tabular}

${ }^{1}$ SoyPlus; West Central Cooperative, Ralston, IA.

${ }^{2}$ Contained a minimum of $5.0 \% \mathrm{Mg}, 7.5 \% \mathrm{~K}, 10.0 \% \mathrm{~S}, 2.0 \% \mathrm{Fe}$, $3.0 \% \mathrm{Mn}, 3.0 \% \mathrm{Zn}, 40 \mathrm{mg} / \mathrm{kg} \mathrm{Co}, 5,000 \mathrm{mg} / \mathrm{kg} \mathrm{Cu}, 250 \mathrm{mg} / \mathrm{kg} \mathrm{I}, 150$ $\mathrm{mg} / \mathrm{kg}$ Se, 2,200 kIU/kg vitamin A, $660 \mathrm{kIU} / \mathrm{kg}$ vitamin D, 22,000 IU/ $\mathrm{kg}$ vitamin $\mathrm{E}$.

${ }^{3}$ Contained 44,000 IU/kg vitamin $\mathrm{E}$.

${ }^{4}$ Nutrient content calculated from analysis of individual ingredients sampled weekly and composited monthly.

tion diet (Table 1) balanced to meet or exceed nutrient requirements for multiparous Holstein cows in early lactation (NRC, 2001). Cows were housed in tie stalls, fed individually, and allowed access to an outdoor loafing pen for at least $1 \mathrm{~h}$ daily. Cows were milked in their stalls twice daily at 0530 and $1730 \mathrm{~h}$. All cows received a subcutaneous injection of bST (Posilac; Monsanto Co., St. Louis, MO) on d 6 of each period. Because our objective was to induce liver lipid infiltration characteristic of the periparturient period by way of acute feed restriction, bST was injected on $\mathrm{d} 6$ so that the peak milk yield response would occur during feed restriction (Bauman et al., 1989), thus maximizing net energy deficit.

\section{Sampling and Analysis of Feed and Milk}

Fresh feed was mixed daily and cows were fed approximately half of their daily allotment of TMR at 0700 and $1800 \mathrm{~h}$. The amount of feed offered and refused was weighed and recorded daily for calculation of daily DMI. Feed refusals from each cow were sampled every
$2 \mathrm{~d}$, composited by period, and analyzed for DM content (AOAC, 1995). Forages, cottonseed, concentrate mixes, and TMR were sampled and analyzed weekly for DM content (AOAC, 1995); ingredient composition (as-fed basis) was adjusted weekly as necessary. Feed samples were stored at $-20^{\circ} \mathrm{C}$, composited monthly, and analyzed by wet chemistry methods for $\mathrm{CP}, \mathrm{ADF}, \mathrm{NDF}, \mathrm{Ca}$, $\mathrm{P}, \mathrm{Mg}$, and $\mathrm{K}$ (Dairy One Cooperative Inc., Ithaca, NY). Total digestible nutrient values were predicted using the Ohio State summative energy equation at $1 \times$ maintenance, $\mathrm{NE}_{\mathrm{L}}$ values were predicted at $3 \times$ maintenance (NRC, 2001), and forage $\mathrm{NE}_{\mathrm{L}}$ was calculated using the Van Soest variable discount method. Nutrient composition of the experimental diet (Table 1) was calculated using analyses of monthly composites of individual ingredients.

Milk yield was measured and recorded after each milking. Milk was sampled $(\sim 120 \mathrm{~mL} /$ milking$)$ from each cow from 4 consecutive milkings on d 8 and 9 and again on d 13 and 14 of each period. Samples from 2 consecutive milkings were composited (4 composites/ period) in proportion to milk yield. A portion $(40 \mathrm{~mL})$ of each composite was preserved (800 Broad Spectrum Microtabs II; D\&F Control Systems, Inc., San Ramon, CA) and analyzed for contents of fat, protein, lactose, and urea N by a commercial lab (Dairy Lab Services, Dubuque, IA) using midinfrared procedures (AOAC, 1995).

Body weight was measured before initiation of treatments. Feed efficiency was calculated as 3.5\% FCM/ DMI. Energy balance was calculated for each cow on d $8,9,13$, and 14 of each period. Daily DMI and calculated dietary $\mathrm{NE}_{\mathrm{L}}$ density were used to calculate $\mathrm{NE}_{\mathrm{L}}$ intake (Mcal/d). Requirements for maintenance (Mcal/d) were calculated as $\mathrm{BW}^{0.75} \times 0.080(\mathrm{NRC}, 2001)$, and $\mathrm{NE}_{\mathrm{L}}$ requirements for milk production $(\mathrm{Mcal} / \mathrm{kg}$ ) were calculated as $[(0.0929 \times$ fat percentage $)+(0.0547 \times$ protein percentage $)+(0.0395 \times$ lactose percentage $)](\mathrm{NRC}$, 2001). The equation used to calculate energy balance $(\mathrm{Mcal} / \mathrm{d})$ was $\left[\mathrm{NE}_{\mathrm{L}}\right.$ intake - (maintenance energy + milk energy output)].

\section{Sampling and Analysis of Blood and Tissue}

Blood was sampled from a coccygeal vessel on d 4, 8, and 12 of each period at 0700,1000 , and $1300(0,3$, and $6 \mathrm{~h}$ relative to the a.m. feeding). In relation to abomasal infusions, blood was sampled 1 and $4 \mathrm{~h}$ after the $0600 \mathrm{~h}$ infusion, and then $1 \mathrm{~h}$ after the $1200 \mathrm{~h}$ infusion. At each timepoint, blood was collected into evacuated tubes (Becton Dickinson Vacutainer Systems, Franklin Lakes, NJ) containing $\mathrm{K}_{3}$ EDTA or sodium fluoride (glycolytic inhibitor) plus potassium oxalate for plasma, or clot activator (SST; Becton Dickinson 
Vacutainer Systems) for serum. Plasma and serum were obtained by centrifugation at $1,300 \times g$ for $10 \mathrm{~min}$ and stored at $-20^{\circ} \mathrm{C}$ for later analysis. Concentrations of urea N (Crocker, 1967) and BHBA (Williamson and Mellanby, 1974) in serum and concentrations of glucose (Peterson and Young, 1968) in plasma (from tubes containing sodium fluoride plus potassium oxalate) were determined using enzymatic kits validated for an autoanalyzer (urea/BUN kit, Roche Diagnostics Corp., Indianapolis, IN; Ranbut kit, Randox Laboratories Ltd., Oceanside, CA; glucose/HK kit, Roche Diagnostics, Inc.). Insulin concentration in serum was analyzed using a radioimmunoassay kit (Coat-a-Count Insulin kit; Diagnostic Products Corporation, Los Angeles, CA) as modified by Studer et al. (1993). The concentration of NEFA in plasma (containing $\mathrm{K}_{3}$ EDTA) was determined enzymatically using a commercial kit (NEFA C; Wako Chemicals USA, Inc., Richmond, VA) with modifications (Johnson and Peters, 1993).

Liver was sampled from cows via puncture biopsy under local anesthesia (2\% lidocaine hydrochloride) on d 14 of each period (Veenhuizen et al., 1991). Tissue (3 to $6 \mathrm{~g}$ ) was blotted onto sterile gauze to remove excess blood and a portion $(\sim 1 \mathrm{~g})$ of fresh liver tissue was placed immediately into ice-cold phosphate-buffered $(9 \mathrm{mM})$ saline $(0.9 \% ; \mathrm{pH}=7.4)$ for transport to the laboratory. The remaining liver tissue was placed into cryogenic vials, frozen immediately, and stored in liquid $\mathrm{N}$ until analysis of total lipid (Hara and Radin, 1978), TG (Fletcher, 1968; Foster and Dunn, 1973), and glycogen (Lo et al., 1970) concentrations.

A biopsy of the semitendinosus muscle was performed immediately prior to the liver biopsy. A local anesthetic (2\% lidocaine hydrochloride) was injected both intermuscularly and subcutaneously distal to the tuber ischia, then a $2-\mathrm{cm}$ incision was made using a sterile scalpel blade. Approximately $200 \mathrm{mg}$ of muscle tissue was removed using a biopsy needle (Bard MAGNUM; 12 gauge $\times 16 \mathrm{~cm}$; C. R. Bard, Inc., Murray Hill, NJ). Muscle tissue was frozen immediately in liquid $\mathrm{N}$ and stored until analysis of glycogen concentration (Lo et al., 1970).

\section{Liver Metabolism}

Within 75 min of the liver biopsy, liver was sliced with a Krumdieck tissue slicer (Alabama Research and Development, Munford, AL) filled with ice-cold PBS. Slices were blotted and weighed into $25-\mathrm{mL}$ Erlenmeyer flasks with $3 \mathrm{~mL}$ of incubation medium containing radiolabeled palmitate, alanine, or propionate to determine rates of conversion to specific labeled end-products. Each flask contained 20 to $60 \mathrm{mg}$ of tissue depending upon the amount of tissue obtained from the biopsy. All incubations were performed in triplicate. Liver slices were incubated at $37^{\circ} \mathrm{C}$ for $2 \mathrm{~h}$ in a shaking water bath; blank flasks were prepared concurrently for each end-product within media types. Radioactivity in labeled end-products was determined by liquid scintillation spectroscopy (model LS6000IC; Beckman Coulter, Inc., Fullerton, CA).

Determination of Palmitate Conversion to Labeled Products. To measure conversion of palmitate to $\mathrm{CO}_{2}$, acid-soluble products (ASP), and intracellular esterified products (EP), incubations were conducted in Krebs-Ringer bicarbonate (KRB) media as described by Drackley et al. (1991b) except that Na-HEPES (25 $\mathrm{m} M$ ) replaced an equimolar portion of $\mathrm{NaCl}$, and $\mathrm{L}$ carnitine was not included. The KRB medium contained Na-palmitate (2 mM; MP Biomedicals, Irvine, CA) and $\left[1-{ }^{14} \mathrm{C}\right]$ palmitate $(0.3 \mu \mathrm{Ci}$; MP Biomedicals $)$ complexed to fatty acid-free BSA (MP Biomedicals) in a 4:1 molar ratio. For $\mathrm{CO}_{2}$ and $\mathrm{ASP}$, incubations were stopped by injecting $0.5 \mathrm{~mL}$ of $40 \% \mathrm{HClO}_{4}$ into the incubation media and $0.1 \mathrm{~mL}$ of $30 \% \mathrm{NaOH}$ was applied directly to folded filter paper in a hanging well. Blank flasks were processed identically except these flasks did not receive liver tissue and were stopped immediately to establish the amount of background radioactivity. After incubations were stopped, live and blank flasks were shaken on ice for $1 \mathrm{~h}$ to collect $\mathrm{CO}_{2}$ in the hanging well. Incubation media and hanging wells were processed as described previously by Drackley et al. (1991b) and transferred to scintillation vials. After processing, $10 \mathrm{~mL}$ of liquid scintillation cocktail (Scintisafe Econo 2; Fisher Scientific, Fair Lawn, NJ) was added to each vial for quantification of radioactivity.

For measurement of palmitate conversion to EP, incubations were conducted in separate flasks that contained the same KRB medium as described for $\mathrm{CO}_{2}$ and ASP measurements; live flasks were incubated similarly except EP flasks did not contain a hanging well. Blank flasks contained liver tissue but the incubations were immediately stopped by aspiration of the incubation media. Following aspiration, $1 \mathrm{~mL}$ of $3 \%$ BSA $\left(37^{\circ} \mathrm{C}\right)$ was added, the flask was vortexed, and the BSA was aspirated; this process was repeated with $3 \mathrm{~mL}$ of saline $(0.9 \%)$ followed by $1 \mathrm{~mL}$ of saline. Triglyceride extraction was conducted according to procedures described by Piepenbrink et al. (2004), except that tubes were centrifuged at $1,000 \times g$, phase separation was conducted in disposable tubes rather than the original glass extraction tube, and scintillation vials containing solvent were dried overnight. When dry, $10 \mathrm{~mL}$ of scintillation cocktail (Scintisafe Econo 2; Fisher Scientific) was added to each vial.

Determination of L-Alanine and Propionate Conversion to Labeled Products. To determine oxi- 
dative and gluconeogenic capacity from L-alanine and propionate, liver slices were incubated in media containing either L-alanine (10 $\mathrm{mM}$; MP Biomedicals) plus $\left[1-{ }^{14} \mathrm{C}\right]$-L-alanine $(1 \mu \mathrm{Ci}$; MP Biomedicals $)$, or Na-propionate $(10 \mathrm{mM}$; American Radiolabeled Chemicals, St. Louis, MO) plus $\left[1-{ }^{14} \mathrm{C}\right]$ propionate $(1 \mu \mathrm{Ci}$; American Radiolabeled Chemicals). The KRB medium was prepared according to procedures of Overton et al. (1999) with modifications (Piepenbrink and Overton, 2003), except that each flask contained $3 \mathrm{~mL}$ of incubation medium instead of $2.4 \mathrm{~mL}$. Determination of the rate of $\mathrm{CO}_{2}$ generation from L-alanine or Na-propionate in live and blank flasks was as described for palmitate oxidation, except that incubations were terminated with $0.5 \mathrm{~mL}$ of $25 \% \mathrm{TCA}$ (wt/vol) rather than $40 \%$ $\mathrm{HClO}_{4}$.

After removal of rubber septa and hanging wells from the flasks, incubation media were processed according to procedures of Piepenbrink and Overton (2003). The 3-column ion-exchange procedure of Mills et al. (1981) was used to isolate $\left[1-{ }^{14} \mathrm{C}\right]$ glucose in processed incubation media. Ion-exchange resins (Sigma Chemical Co., St. Louis, MO) were used as described by Mills et al. (1981), and $\left[{ }^{3} \mathrm{H}\right] \mathrm{L}$-1-glucose (Sigma Chemical Co.) was used as an internal standard to account for losses of radioactivity during processing.

\section{Carnitine Analysis}

Total carnitine concentration in liver was determined by an enzymatic radioisotope method (McGarry and Foster, 1976) with modifications (Bhuiyan et al., 1992). Initially, liver tissue $(0.2 \mathrm{~g})$ was homogenized in icecold $\mathrm{HClO}_{4}(1 \mathrm{~mol} / \mathrm{L})$ in a 2 -mL microcentrifuge tube. Further extractions were conducted to sequentially hydrolyze free carnitine and carnitine esters to allow for quantification of individual fractions (Lin and Odle, 2003). Carnitine concentrations in extraction supernatants were determined using the enzymatic radioisotope method described by Lin and Odle (2003). Radioactivity in ion-exchange column effluent was quantified by liquid scintillation spectroscopy. Total carnitine was defined as the sum of acid-soluble carnitine (free carnitine plus short-chain acylcarnitine) and long-chain acylcarnitine.

\section{Statistical Analysis}

For in vitro liver incubations, conversion to end-products was calculated using the known amount of radioactivity present in each flask relative to the amount of radioactivity measured in end-products following the 2 -h incubation period. Substrate conversion rates were corrected for tissue weight and radioactivity in blank flasks.
One cow was removed from the experiment because of poor recovery from rumen cannulation surgery; consequently, the analysis included data from 7 cows. One cow developed clinical mastitis during an experimental period (WA treatment) and milk production declined substantially; therefore, data were removed for that period. As a result of intramammary therapy for mastitis, the cow recovered and data were included for the other experimental periods.

Intake, milk production, and milk composition data obtained during $d 5$ to 9 (ad libitum feeding) were analyzed separately from data obtained during d 10 to 14 (ad libitum or restricted feeding). Blood data were separated by day and analyzed individually to account for treatment changes within period (infusion vs. infusion $\times$ DMI effects). The experiment was conducted and analyzed as a replicated $4 \times 4$ Latin square design with a $2 \times 2$ factorial arrangement of treatments. Data were analyzed using the MIXED procedure of SAS (SAS Institute Inc., Cary, NC). Effects of square, infusion type, and intake amount were included as fixed effects; random effects of cow and period nested within square were used as the error term to test fixed effects. The fixed effect of square was not significant and was removed from the model. The effects of hour and day were included as fixed repeated effects, and all associated interactions of infusion type, intake amount, day, and hour were included where appropriate. Degrees of freedom were estimated with the Satterthwaite specification in the model statement. The REPEATED statement was used for blood and production data; the error term in the REPEATED statement was cow $\times$ period nested within square. The covariance structure that yielded the lowest Akaike's information criterion was used for repeated measurements (Littell et al., 1998). Significance of the $F$-test of fixed effects was declared at $P \leq$ 0.05 and trends discussed when $0.05<P \leq 0.15$. Where appropriate, least squares means for interactions were separated using the "lsmeans/pdiff" statement in SAS when protected by the $F$-test $(P \leq 0.15)$.

\section{RESULTS}

\section{Intake, Milk Yield, Milk Composition, and Energy Balance}

The ingredient and nutrient composition of the diet is detailed in Table 1. Balance of MP and predicted duodenal supply of Lys and Met are shown in Table 2 (NRC, 2001). Carnitine infusion did not influence DMI, milk yield (Figure 1), 3.5\% FCM yield, $\mathrm{NE}_{\mathrm{L}}$ balance, or feed efficiency from d 5 to 9 ( $P>0.53$; Table 3$)$. Likewise, carnitine infusion did not affect concentrations or yields of milk fat and milk lactose on d 8 to $9(P>0.46$; Table 4). Milk protein percentage tended to be lower in milk 
Table 2. National Research Council (2001) model inputs and estimates used to predict MP balance and Met and Lys as percentages of MP for lactating Holstein cows fed for ad libitum or restricted DMI

\begin{tabular}{lcc}
\hline & \multicolumn{2}{c}{ Amount of intake } \\
\cline { 2 - 3 } Variable & $\begin{array}{l}\text { Ad libitum DMI } \\
\text { (d 5 to 9) }\end{array}$ & $\begin{array}{l}\text { Restricted DMI } \\
\text { (d 10 to 14) }\end{array}$ \\
\hline DMI, kg & 25.1 & 12.1 \\
BW, kg & 635 & 635 \\
BCS & 2.75 & 2.75 \\
DIM & 132 & 132 \\
Milk, kg/d & 33.7 & 28.8 \\
Fat, \% & 3.91 & 3.89 \\
Protein, \% & 2.98 & 2.81 \\
Lactose, \% & 4.84 & 4.76 \\
Estimates 1 & & \\
MP required, g/d & 2,378 & 1,686 \\
MP supplied, g/d & 2,828 & 1,308 \\
MP balance, g/d & 451 & -379 \\
Met, \% of MP & 1.80 & 1.90 \\
Lys, \% of MP & 6.37 & 6.83 \\
\hline
\end{tabular}

${ }^{1}$ Nutrient composition of monthly composites used for corn silage, alfalfa silage, and cottonseed; default values (NRC, 2001) used for nutrient composition of concentrates.

from cows infused with carnitine compared with those infused with water (2.96 vs. $2.99 \pm 0.07 \%$, respectively; $P=0.11$ ), whereas milk protein yield was similar among treatments.

During d 10 to 14, feed-restricted cows were offered $50 \%$ of the average DM consumed during d 5 to 9 . As a result of feed restriction, cows were in negative balances for energy (Table 3) and MP (Table 2) on d 13 and 14 . Feed restriction reduced milk yield by $19 \%$ compared with cows fed ad libitum; milk yield decreased gradually from d 10 to 12 but remained stable from d 12 to 14 (Figure 1). L-Carnitine infusion did not alter DMI, milk yield, or milk component concentrations during feed restriction. However, yield of 3.5\% FCM was higher for the CR treatment than for the WR treatment (infusion $\times \mathrm{DMI}, P=0.03$ ), thereby resulting in increased apparent feed efficiency during feed restriction (infusion $\times$ DMI, $P=0.03$ ). Energy balance was increased by carnitine infusion in ad libitum-fed cows, but was reduced by carnitine infusion in feedrestricted cows (infusion $\times$ DMI, $P<0.01$ ). Feed restriction decreased milk protein concentration, milk protein yield, and milk lactose percentage $(P<0.01)$, whereas milk urea $\mathrm{N}$ increased $(P<0.01)$. Milk fat concentration was unaffected by feed restriction $(P=0.79)$, but carnitine infusion increased milk fat yield in feed-restricted cows (infusion $\times$ DMI, $P=0.03$ ).

\section{Blood Metabolites and Hormones}

The concentrations of NEFA, BHBA, insulin, and urea $\mathrm{N}$ in serum and glucose in plasma are reported in
Table 5 as the means of samples collected at 0,3 , and $6 \mathrm{~h}$ relative to feeding. Plasma NEFA concentrations were not different between infusion treatments on $\mathrm{d} 4$ and $\mathrm{d} 8$. On $\mathrm{d} 12$, feed restriction increased plasma NEFA $(P<0.01)$ at 0 and $6 \mathrm{~h}$ relative to feeding (hour $\times$ DMI, $P<0.01$; data not shown) in a similar fashion for both WR and CR treatments; infusion type and amount of DMI did not interact significantly.

Serum BHBA concentration was similar among treatments on d 4 and 8 . Hour relative to feeding affected serum BHBA $(P<0.01)$ such that concentrations increased from 0 to $3 \mathrm{~h}$ postfeeding on all sampling days (data not shown). On d 12, feed restriction and carnitine infusion caused changes in serum BHBA at $3 \mathrm{~h}$ and 6 h (hour $\times$ infusion $\times$ DMI, $P=0.03$; Figure 2 ). At $3 \mathrm{~h}$ postfeeding, the WA treatment had higher serum BHBA than did WR and CR, though CA was statistically similar to the other treatments. At $6 \mathrm{~h}$ postfeeding, concentrations of BHBA in serum were equivalent between WA $(6.5 \pm 0.6 \mathrm{mg} / \mathrm{dL})$ and $\mathrm{CR}(6.4 \mathrm{mg} / \mathrm{dL})$, whereas both were significantly higher than WR (3.6 $\mathrm{mg} / \mathrm{dL})$ and $\mathrm{CA}(4.0 \mathrm{mg} / \mathrm{dL})$.

Insulin concentration in serum did not differ due to treatment on $\mathrm{d} 4$ and 8 . On d 12 , feed restriction reduced serum insulin compared with cows fed ad libitum; however, WA cows had greater serum insulin than CA (infusion $\times$ DMI, $P=0.04$ ). Plasma glucose concentration was similar among treatments on $\mathrm{d} 4$. On d 8 , carnitine infusion increased mean plasma glucose concentration $(P=0.03)$ with differences occurring at $6 \mathrm{~h}$ postfeeding (hour $\times$ infusion, $P=0.10$ ). On $d 12$, prefeeding (h 0 ) plasma glucose tended to be higher for the CA treatment than for WA, WR, and CR (hour $\times$ infusion $\times$ DMI, $P=0.09$ ), but no differences were detected at 3 or $6 \mathrm{~h}$ (data not shown).

Serum urea $\mathrm{N}$ was different among treatments on d 4 , where at $3 \mathrm{~h}$ the WR treatment had higher serum urea $\mathrm{N}$ than other treatments but at $6 \mathrm{~h}$ urea $\mathrm{N}$ was elevated for WA compared with other treatments (hour $\times$ infusion $\times$ DMI, $P<0.01$ ). Major differences among treatments were unexpected as cows were neither receiving infusion treatment nor subjected to feed restriction; differences may have resulted from variability in recovery from feed restriction or tissue biopsies in previous periods. On d 8, carnitine infusion significantly reduced serum urea $\mathrm{N}$ concentration $(P=0.05)$. During feed restriction, neither amount of DMI nor infusion type had a clear impact on serum urea $\mathrm{N}$; however, the $\mathrm{CA}$ treatment tended to have lower serum urea $\mathrm{N}$ at $6 \mathrm{~h}$ postfeeding compared with the other treatments (hour $\times$ infusion $\times \mathrm{DMI}, P=0.07$ ) .

\section{Tissue Composition and In Vitro Hepatic Metabolism}

Total carnitine concentration was determined in liver tissue obtained on d 14 of each period (Table 6). Carni- 
A

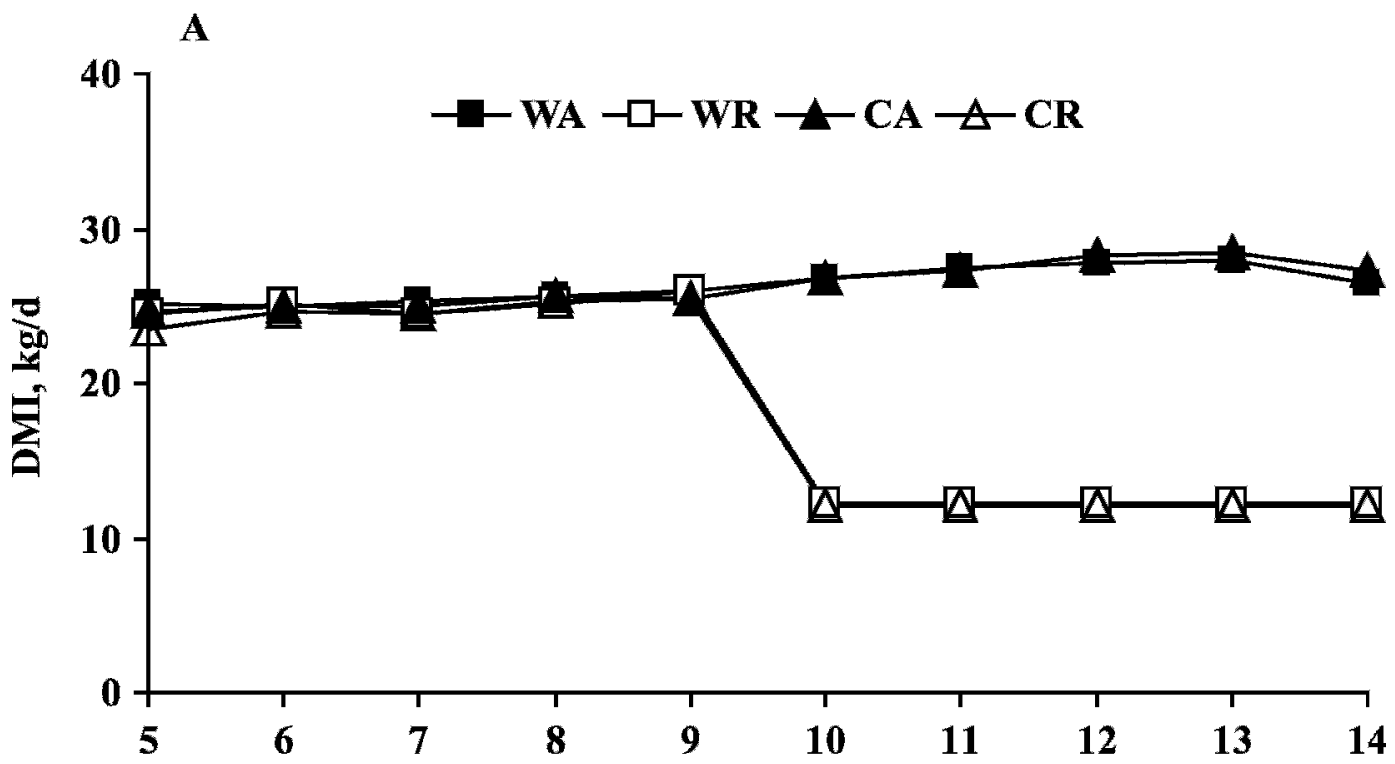

B

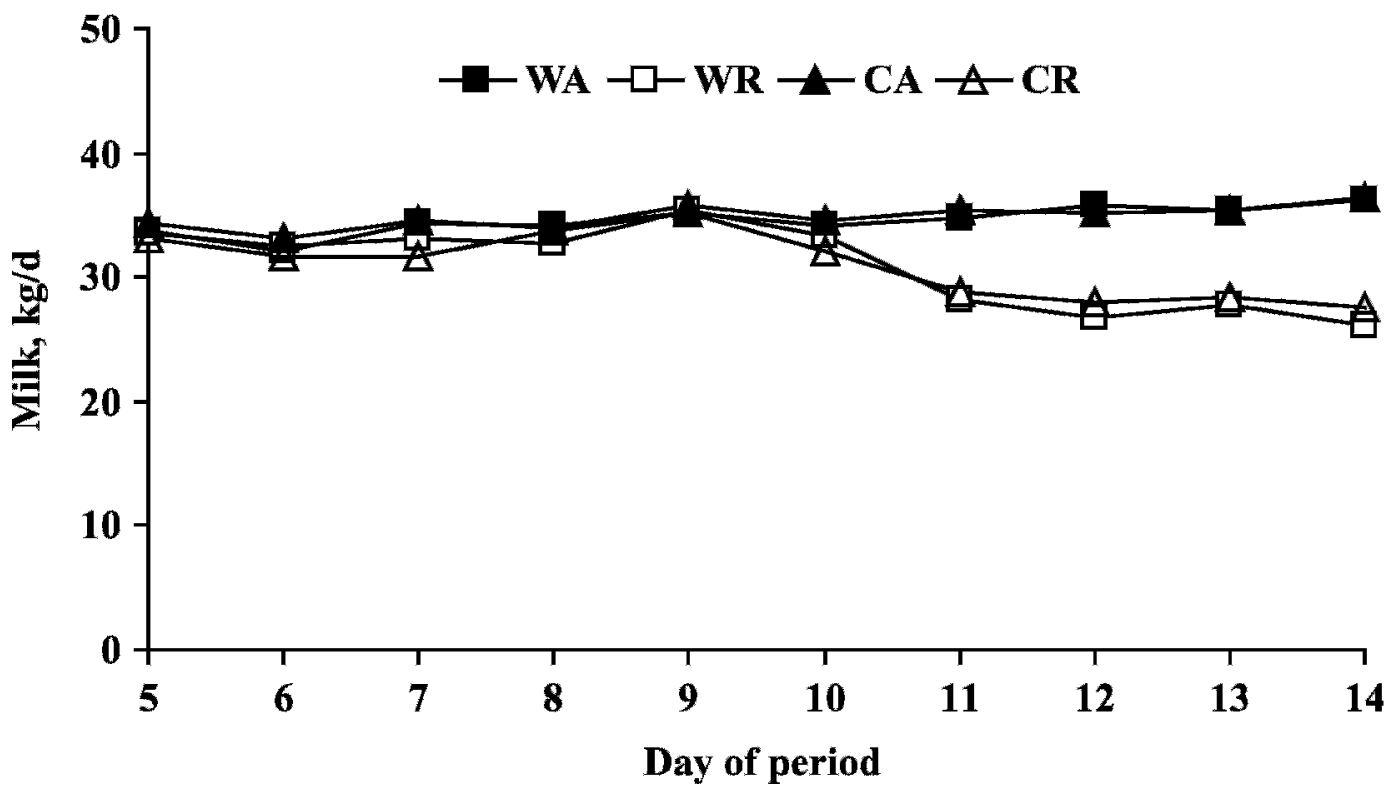

Figure 1. Least squares means for A) DMI, and B) milk yield of lactating Holstein cows infused with water or L-carnitine (20 g/d; d 5 to 14) and fed for ad libitum or restricted DMI (50\% of previous 5-d DMI; d 10 to 14). Treatments: WA = water infusion, ad libitum DMI; $\mathrm{WR}$ = water infusion, restricted DMI; CA = carnitine infusion, ad libitum DMI; CR = carnitine infusion, restricted DMI. Panel A. Fixed effects in model (d 5 to 9 , SEM $=1.0$ ): infusion, $P=0.54$; DMI, $P=0.42$; infusion $\times$ DMI, $P=0.94$. Fixed effects in model (d 10 to 14 , SEM $=$ 0.7): infusion, $P=0.94$; DMI, $P<0.01$; infusion $\times$ DMI, $P=0.63$. Panel B. Fixed effects in model (d 5 to 9 , SEM $=1.6$ ): infusion, $P=0.90$; DMI, $P=0.11$; infusion $\times$ DMI, $P=0.41$. Fixed effects in model (d 10 to 14 , SEM $=1.5$ ): infusion, $P=0.68$; DMI, $P<0.01$; infusion $\times$ DMI, $P=0.72$.

tine infusion increased hepatic total carnitine concentration compared with water infusion; however, the CR treatment resulted in higher total carnitine than did the CA treatment (infusion $\times \mathrm{DMI}, P=0.02$ ). Interestingly, feed restriction had little effect on liver total carnitine concentration in water-infused cows because WA and WR treatments were statistically similar $(P>0.15)$.
Total lipid and TG concentrations in liver tissue were determined on d 14 of each period (Table 6). In feedrestricted cows, L-carnitine infusion decreased total lipid concentration (infusion $\times \mathrm{DMI}, P=0.05$ ) and tended to reduce TG concentration (infusion $\times$ DMI, $P=$ 0.08 ) compared with cows infused with water. Carnitine infusion prevented lipid and TG accumulation in liver 
Table 3. Least squares means for 3.5\% FCM yield, feed efficiency, and $\mathrm{NE}_{\mathrm{L}}$ balance of lactating Holstein cows infused with water or L-carnitine $(20 \mathrm{~g} / \mathrm{d}$; $\mathrm{d} 5$ to 14$)$ and fed for ad libitum or restricted DMI (50\% of previous 5-d DMI; d 10 to 14)

\begin{tabular}{|c|c|c|c|c|c|c|c|c|}
\hline \multirow[b]{3}{*}{ Variable } & \multirow{2}{*}{\multicolumn{4}{|c|}{ Treatment $^{1}$}} & \multirow[b]{3}{*}{ SEM } & \multicolumn{3}{|c|}{$P$-value } \\
\hline & & & & & & & & Infusion \\
\hline & WA & WR & $\mathrm{CA}$ & $\mathrm{CR}$ & & Infusion & DMI & $\times \mathrm{DMI}$ \\
\hline \multicolumn{9}{|c|}{$3.5 \% \mathrm{FCM}^{2}, \mathrm{~kg} / \mathrm{d}$} \\
\hline d 8 to 9 & 37.7 & 36.4 & 37.2 & 36.5 & 2.4 & 0.88 & 0.45 & 0.84 \\
\hline d 13 to 14 & 38.7 & 27.7 & 37.4 & 29.8 & 1.9 & 0.58 & $<0.01$ & 0.03 \\
\hline \multicolumn{9}{|c|}{ Feed efficiency ${ }^{3}$} \\
\hline d 8 to 9 & 1.45 & 1.42 & 1.46 & 1.44 & 0.09 & 0.79 & 0.67 & 0.94 \\
\hline d 13 to 14 & 1.42 & 2.27 & 1.34 & 2.48 & 0.10 & 0.30 & $<0.01$ & 0.03 \\
\hline \multicolumn{9}{|c|}{ Energy balance, mcal/d } \\
\hline d 8 to 9 & 11.2 & 11.7 & 11.0 & 11.1 & 1.5 & 0.70 & 0.84 & 0.84 \\
\hline d 13 to 14 & 12.2 & -5.4 & 14.2 & -7.2 & 0.9 & 0.91 & $<0.01$ & 0.01 \\
\hline
\end{tabular}

${ }^{1} \mathrm{WA}=$ Water infusion, ad libitum DMI; WR = water infusion, restricted DMI; CA = carnitine infusion, ad libitum DMI; CR = carnitine infusion, restricted DMI.

${ }^{2} 3.5 \%$ FCM yield $=(0.4255 \times$ milk yield $)+(16.425 \times$ milk fat yield $)$.

${ }^{3} 3.5 \% \mathrm{FCM}$ yield/DMI.

during feed restriction; means for the CR treatment were similar to those for WA and CA.

Liver tissue was incubated with $\left[1-{ }^{14} \mathrm{C}\right]$ palmitate and conversion to radiolabeled $\mathrm{CO}_{2}, \mathrm{ASP}$, and $\mathrm{EP}$ was determined (Table 6). Postruminal infusion of carnitine did not alter the rate of $\left[1-{ }^{14} \mathrm{C}\right]$ palmitate conversion to $\mathrm{CO}_{2}(P=0.25)$ but significantly increased conversion of palmitate to ASP $(P=0.02)$. Likewise, infusion of carnitine did not affect the proportion of palmitate oxidized to $\mathrm{CO}_{2}$ (as percentage of total palmitate metabo- lism; $P=0.19)$ but the percentage of palmitate converted to ASP was increased $(P=0.02)$. Feed restriction did not affect the rate of palmitate oxidation $(P \geq 0.40)$ or the proportion of palmitate oxidized to $\mathrm{CO}_{2}(P=0.99)$ or ASP $(P=0.17)$. The rate of palmitate conversion to EP was not different among infusion treatments $(P=$ 0.65 ), but carnitine infusion decreased the percentage of palmitate converted to $\mathrm{EP}(P=0.02)$. Amount of intake did not alter parameters associated with palmitate conversion to $\mathrm{EP}(P>0.16)$. Interactions of infusion

Table 4. Least squares means for concentrations and yields of fat, protein, lactose, and urea $\mathrm{N}$ in milk from lactating Holstein cows infused with water or L-carnitine $(20 \mathrm{~g} / \mathrm{d}$; d 5 to 14$)$ and fed for ad libitum or restricted DMI (50\% of previous 5-d DMI; d 10 to 14)

\begin{tabular}{|c|c|c|c|c|c|c|c|c|}
\hline \multirow[b]{3}{*}{ Milk component } & \multirow{2}{*}{\multicolumn{4}{|c|}{ Treatment $^{1}$}} & \multirow[b]{3}{*}{ SEM } & \multicolumn{3}{|c|}{$P$-value } \\
\hline & & & & & & & & Infusion \\
\hline & WA & WR & CA & $\mathrm{CR}$ & & Infusion & DMI & $\times$ DMI \\
\hline \multicolumn{9}{|l|}{ Fat, \% } \\
\hline d 8 to 9 & 4.05 & 3.80 & 3.80 & 4.00 & 0.19 & 0.90 & 0.89 & 0.20 \\
\hline d 13 to 14 & 3.97 & 3.85 & 3.73 & 3.92 & 0.13 & 0.47 & 0.79 & 0.21 \\
\hline \multicolumn{9}{|l|}{ Fat, kg/d } \\
\hline d 8 to 9 & 1.40 & 1.32 & 1.35 & 1.35 & 0.11 & 0.90 & 0.58 & 0.54 \\
\hline d 13 to 14 & 1.42 & 1.01 & 1.34 & 1.09 & 0.08 & 0.99 & $<0.01$ & 0.03 \\
\hline \multicolumn{9}{|l|}{ Protein, \% } \\
\hline d 8 to 9 & 3.00 & 2.98 & 2.96 & 2.95 & 0.08 & 0.11 & 0.55 & 0.79 \\
\hline d 13 to 14 & 3.03 & 2.81 & 3.02 & 2.81 & 0.08 & 0.80 & $<0.01$ & 0.82 \\
\hline \multicolumn{9}{|l|}{ Protein, kg/d } \\
\hline d 8 to 9 & 1.05 & 1.03 & 1.04 & 0.98 & 0.05 & 0.23 & 0.10 & 0.40 \\
\hline d 13 to 14 & 1.11 & 0.73 & 1.10 & 0.78 & 0.05 & 0.53 & $<0.01$ & 0.33 \\
\hline \multicolumn{9}{|l|}{ Lactose, \% } \\
\hline d 8 to 9 & 4.85 & 4.82 & 4.85 & 4.83 & 0.05 & 0.80 & 0.23 & 0.66 \\
\hline d 13 to 14 & 4.91 & 4.73 & 4.88 & 4.78 & 0.05 & 0.81 & $<0.01$ & 0.37 \\
\hline \multicolumn{9}{|l|}{ Urea $\mathrm{N}, \mathrm{mg} / \mathrm{dL}$} \\
\hline d 8 to 9 & 10.28 & 11.69 & 10.68 & 11.07 & 1.25 & 0.82 & 0.10 & 0.34 \\
\hline d 13 to 14 & 11.12 & 14.15 & 11.01 & 13.71 & 1.13 & 0.63 & $<0.01$ & 0.77 \\
\hline
\end{tabular}

${ }^{1} \mathrm{WA}=$ Water infusion, ad libitum DMI; WR = water infusion, restricted DMI; CA $=$ carnitine infusion, ad libitum DMI; CR = carnitine infusion, restricted DMI. 
Table 5. Least squares means for concentrations of NEFA, BHBA, insulin, glucose, and urea $\mathrm{N}$ in serum or plasma from lactating Holstein cows infused with water or L-carnitine (20 g/d; d 5 to 14$)$ and fed for ad libitum or restricted DMI (50\% of previous 5-d DMI; d 10 to 14$)^{1}$

\begin{tabular}{|c|c|c|c|c|c|c|c|c|c|}
\hline \multirow[b]{3}{*}{ Item } & \multirow{2}{*}{\multicolumn{4}{|c|}{ Treatment $^{2}$}} & \multirow[b]{3}{*}{ SEM } & \multicolumn{4}{|c|}{$P$-value } \\
\hline & & & & & & & & Infusion & \\
\hline & WA & WR & CA & $\mathrm{CR}$ & & Infusion & DMI & $\times$ DMI & Treatment $\times$ Time $^{3}$ \\
\hline \multicolumn{10}{|l|}{ NEFA, $\mu \mathrm{Eq} / \mathrm{L}$} \\
\hline d 4 & 62.0 & 73.2 & 66.6 & 71.4 & 8.4 & 0.82 & 0.21 & 0.60 & \multirow[b]{3}{*}{$\mathrm{h} \times \mathrm{DMI}^{*}$} \\
\hline d 8 & 74.3 & 82.5 & 68.4 & 87.2 & 10.1 & 0.94 & 0.10 & 0.50 & \\
\hline d 12 & 73.9 & 232.6 & 67.0 & 200.5 & 25.4 & 0.38 & $<0.01$ & 0.57 & \\
\hline \multicolumn{10}{|l|}{ BHBA, mg/dL } \\
\hline d 4 & 5.7 & 4.8 & 5.5 & 5.3 & 0.6 & 0.83 & 0.34 & 0.59 & \multirow[b]{3}{*}{$\mathrm{h} \times$ infusion $\times \mathrm{DMI}^{*}$} \\
\hline d 8 & 5.1 & 4.9 & 5.6 & 5.1 & 0.4 & 0.41 & 0.43 & 0.64 & \\
\hline d 12 & 6.2 & 4.5 & 4.9 & 5.7 & 0.4 & 0.85 & 0.12 & $<0.01$ & \\
\hline \multicolumn{10}{|l|}{ Insulin, $\mu \mathrm{IU} / \mathrm{mL}$} \\
\hline d 4 & 8.8 & 10.0 & 9.2 & 9.3 & 1.7 & 0.92 & 0.66 & \multicolumn{2}{|l|}{0.72} \\
\hline d 8 & 10.2 & 10.8 & 10.0 & 11.5 & 1.5 & 0.84 & 0.42 & \multicolumn{2}{|l|}{0.72} \\
\hline d 12 & 10.7 & 5.7 & 8.9 & 6.6 & 0.9 & 0.47 & $<0.01$ & \multicolumn{2}{|l|}{0.04} \\
\hline \multicolumn{10}{|l|}{ Glucose, mg/dL } \\
\hline d 4 & 63.2 & 62.3 & 64.4 & 63.9 & 1.6 & 0.15 & 0.45 & 0.83 & \multirow{3}{*}{$\begin{array}{l}\mathrm{h} \times \text { infusion } * * \\
\mathrm{~h} \times \text { infusion } \times \mathrm{DMI}^{* *}\end{array}$} \\
\hline d 8 & 61.7 & 63.2 & 64.9 & 63.9 & 1.7 & 0.03 & 0.77 & 0.14 & \\
\hline d 12 & 61.9 & 61.9 & 62.3 & 61.1 & 1.6 & 0.82 & 0.55 & 0.55 & \\
\hline \multicolumn{10}{|l|}{ Urea N, mg/dL } \\
\hline d 4 & 14.9 & 14.3 & 13.1 & 12.9 & 1.3 & 0.19 & 0.72 & 0.89 & \multirow[t]{2}{*}{$\mathrm{h} \times$ infusion $\times \mathrm{DMI}^{*}$} \\
\hline d 8 & 13.8 & 15.1 & 11.8 & 13.7 & 1.3 & 0.05 & 0.07 & 0.69 & \\
\hline d 12 & 13.5 & 12.6 & 12.7 & 12.5 & 1.0 & 0.59 & 0.47 & 0.64 & $\mathrm{~h} \times$ infusion $\times \mathrm{DMI}^{* *}$ \\
\hline
\end{tabular}

${ }^{1}$ Values are averages of concentrations at $\mathrm{h} 0,3$, and 6 relative to feeding.

${ }^{2} \mathrm{WA}=$ Water infusion, ad libitum DMI; WR = water infusion, restricted DMI; CA = carnitine infusion, ad libitum DMI; CR = carnitine infusion, restricted DMI.

$3 *=$ Interaction of treatment and time $(P \leq 0.05) ; * *$ interaction of treatment and time $(0.05<P \leq 0.15)$.

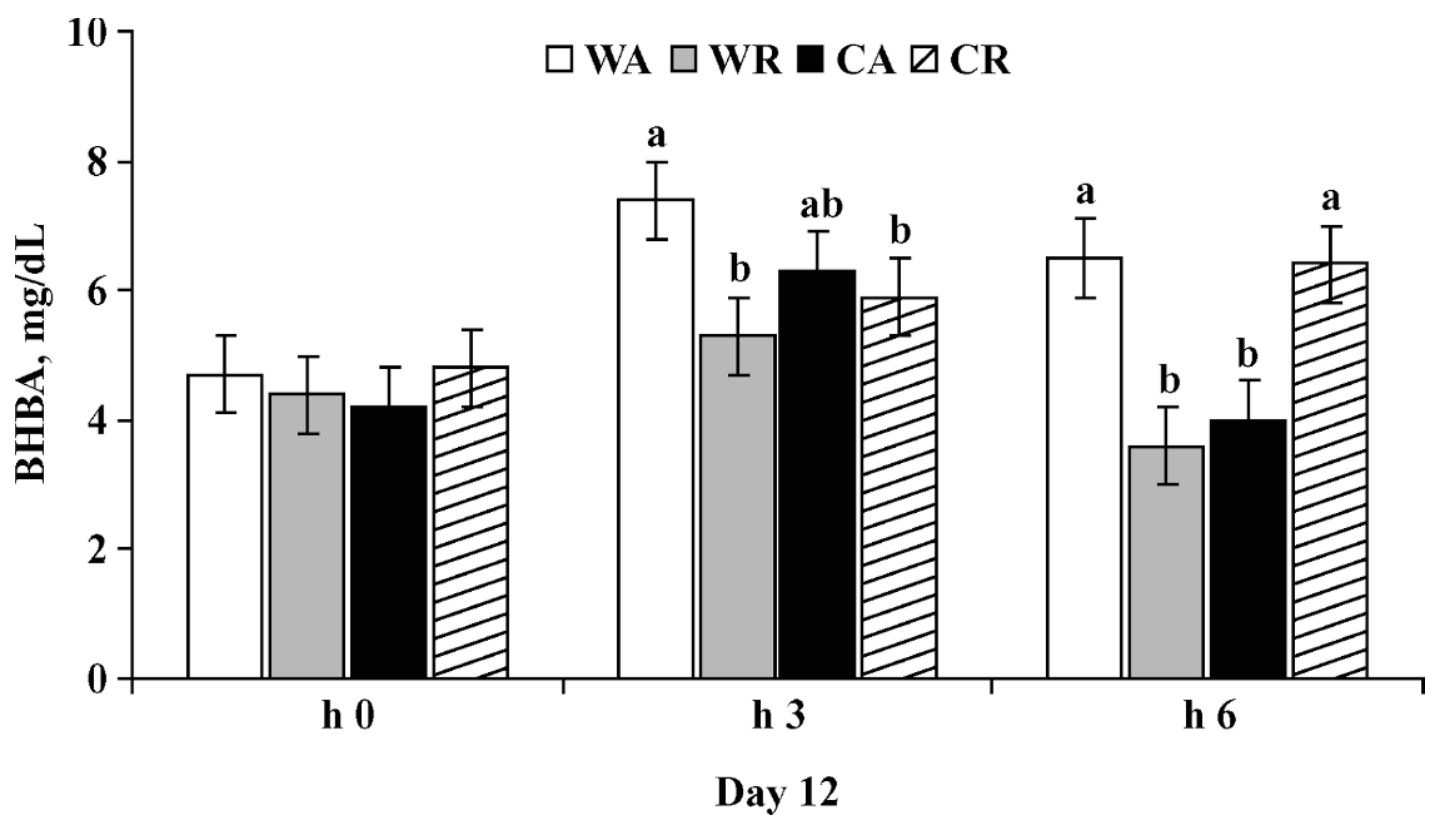

Figure 2. Least squares means and associated standard errors for serum BHBA concentration of lactating Holstein cows infused with water or L-carnitine $(20 \mathrm{~g} / \mathrm{d}$; d 5 to 14$)$ and fed for ad libitum or restricted DMI (50\% of previous 5-d DMI; d 10 to 14). Treatments: WA = water infusion, ad libitum DMI; WR = water infusion, restricted DMI; CA = carnitine infusion, ad libitum DMI; CR = carnitine infusion, restricted DMI. Samples were obtained at 0,3 , and 6 h relative to feeding on d 12. Fixed effects in model: infusion, $P=0.85 ;$ DMI, $P=0.12$; infusion $\times$ DMI, $P<0.01$; hour, $P<0.01$; hour $\times$ infusion, $P=0.87$; hour $\times$ DMI, $P=0.22$; hour $\times$ infusion $\times$ DMI, $P=0.03$. Treatment differences within sampling hour are indicated by unlike letters $(P \leq 0.05)$. 
Table 6. Least squares means for concentrations of total carnitine, total lipid, and triglyceride in liver tissue and in vitro conversion of [1${ }^{14} \mathrm{C}$ ] palmitate to $\mathrm{CO}_{2}$, acid-soluble products, and intracellular esterified products by liver slices from lactating Holstein cows infused with water or L-carnitine ( $20 \mathrm{~g} / \mathrm{d}$; d 5 to 14$)$ and fed for ad libitum or restricted DMI (50\% of previous 5-d DMI; d 10 to 14)

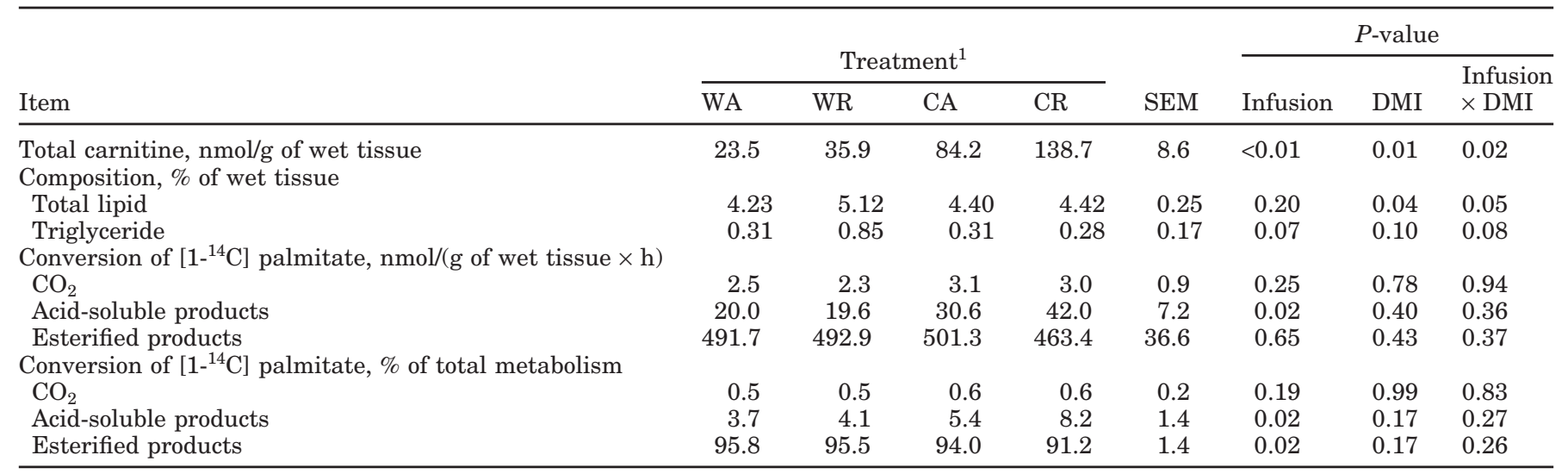

${ }^{1} \mathrm{WA}=$ Water infusion, ad libitum DMI; WR = water infusion, restricted DMI; CA = carnitine infusion, ad libitum DMI; CR = carnitine infusion, restricted DMI.

type and amount of intake were not significant for any measure associated with palmitate metabolism $(P>$ $0.25)$.

Feed restriction decreased liver glycogen in a similar fashion for both WR and CR compared with WA (infusion $\times$ DMI, $P=0.05$; Table 7). Liver glycogen concentration was lower for CA compared with WA, but CA was similar to that for WR and CR. Muscle glycogen concentration (Table 7) was lower in feed-restricted cows than in cows fed ad libitum $(P=0.01)$, independent of infusion type (infusion $\times \mathrm{DMI}, P=0.18$ ).

In vitro conversion of $\left[1-{ }^{14} \mathrm{C}\right] \mathrm{L}$-alanine to $\mathrm{CO}_{2}$ was higher in liver slices from the CA treatment compared with other treatments (infusion $\times \mathrm{DMI}, P=0.04$; Table 7 ). The rate of alanine conversion to glucose was not altered significantly by treatment despite the numerical increase observed in the CA treatment. Conversion of propionate to $\mathrm{CO}_{2}$ (Table 7) was markedly reduced by feed restriction $(P=0.02)$ but was unaffected by carnitine infusion $(P=0.89)$, whereas rates of propionate conversion to glucose did not differ among treatments $(P>0.56)$.

\section{DISCUSSION}

The production data obtained during d 5 to 9 (prior to feed restriction) agree with previous research in which milk production, milk composition, and energy balance were not influenced by postruminal infusion of carnitine to cows fed ad libitum (LaCount et al., 1995, 1996a). Milk protein concentrations were lower in carnitineinfused cows on 8 to 9; previous experiments examining both abomasal infusion (LaCount et al., 1995, 1996a) and dietary supplementation (LaCount et al., 1996b) of carnitine found no differences among treatments for milk protein concentration as well as distribu-

Table 7. Least squares means for concentration of glycogen in liver and muscle tissue and in vitro conversion of $\left[1-{ }^{14} \mathrm{C}\right] \mathrm{L}-\mathrm{alanine}$ and $[1-$ ${ }^{14} \mathrm{C}$ ] propionate to $\mathrm{CO}_{2}$ and glucose by liver slices from lactating Holstein cows infused with water or L-carnitine $(20 \mathrm{~g} / \mathrm{d}$; d 5 to 14$)$ and fed for ad libitum or restricted DMI (50\% of previous 5-d DMI; d 10 to 14)

\begin{tabular}{|c|c|c|c|c|c|c|c|c|}
\hline \multirow[b]{3}{*}{ Item } & \multirow{2}{*}{\multicolumn{4}{|c|}{ Treatment $^{1}$}} & \multirow[b]{3}{*}{ SEM } & \multicolumn{3}{|c|}{$P$-value } \\
\hline & & & & & & & & $\overline{\text { Infusion }}$ \\
\hline & $\overline{\mathrm{WA}}$ & WR & $\mathrm{CA}$ & $\mathrm{CR}$ & & Infusion & DMI & $\times \mathrm{DMI}$ \\
\hline \multicolumn{9}{|c|}{ Composition, $\%$ wet tissue } \\
\hline Liver glycogen & 4.67 & 2.98 & 3.75 & 3.50 & 0.44 & 0.57 & 0.01 & 0.05 \\
\hline Muscle glycogen & 0.45 & 0.38 & 0.52 & 0.32 & 0.08 & 0.88 & 0.01 & 0.18 \\
\hline \multicolumn{9}{|c|}{ Conversion of $\left[1-{ }^{14} \mathrm{C}\right] \mathrm{L}$-alanine, $\mu \mathrm{mol} /(\mathrm{g}$ of wet tissue $\times \mathrm{h})$} \\
\hline $\mathrm{CO}_{2}$ & 0.44 & 0.44 & 0.58 & 0.47 & 0.03 & $<0.01$ & 0.05 & 0.04 \\
\hline $\mathrm{CO}_{2}$ & 3.87 & 2.98 & 4.06 & 2.88 & 0.46 & 0.89 & 0.02 & 0.70 \\
\hline Glucose & 1.71 & 1.60 & 1.45 & 1.42 & 0.49 & 0.57 & 0.86 & 0.91 \\
\hline
\end{tabular}

${ }^{1} \mathrm{WA}=$ Water infusion, ad libitum DMI; WR = water infusion, restricted DMI; CA = carnitine infusion, ad libitum DMI; CR = carnitine infusion, restricted DMI. 
tion of milk N between true protein and NPN. Erfle et al. (1974) reported that milk protein percentage was negatively correlated with milk carnitine concentration in both healthy and ketotic cows in early lactation, perhaps due to use of AA for carnitine biosynthesis rather than milk protein synthesis. Although milk carnitine was increased by carnitine infusion (data not shown), the mechanism proposed by Erfle et al. (1974) is likely not applicable in the current study because carnitine was supplied exogenously and cows were in positive balances of energy and MP during d 5 to 9 . The mechanism by which exogenous carnitine reduced milk protein concentration in cows fed ad libitum is unclear.

Feed restriction of lactating Holstein cows affected $\mathrm{NE}_{\mathrm{L}}$ balance and yields of milk fat, milk protein, and milk lactose as anticipated based on observations of others using a similar feed restriction protocol (Velez and Donkin, 2005). Net energy balance was altered by carnitine infusion in cows fed for ad libitum DMI and those at restricted DMI due to numerical differences in milk fat and lactose concentrations; milk energy output was affected despite nearly identical milk yields within each amount of DMI. Carnitine infusion during feed restriction resulted in a $2.1-\mathrm{kg} / \mathrm{d}$ increase of FCM. The CR treatment resulted in higher milk fat yield than WR (1.09 vs. $1.01 \pm 0.08 \mathrm{~kg} / \mathrm{d}$ ) perhaps as a consequence of higher BHBA and equivalent NEFA concentrations during feed restriction. Nielsen et al. (2003) reported that plasma BHBA was correlated positively with concentrations of BHBA in milk from feed-restricted cows. Blood precursors for milk fat synthesis may have been more abundant because the liver of CR cows had greater capacity to oxidize NEFA to ketone bodies and acetate as opposed to accumulating mobilized NEFA as liver TG. These results suggest that carnitine may support higher FCM yield during negative energy and MP balances.

On d 12, feed restriction clearly caused NEFA release from adipose tissue in agreement with other research employing a similar degree of feed restriction during lactation (Velez and Donkin, 2005). Carnitine infusion did not alter plasma NEFA concentrations in feed-restricted cows; in contrast, intravenous infusion of DLcarnitine $(23.8 \mathrm{~g} / \mathrm{d})$ into feed-restricted or spontaneously ketotic cows consistently reduced blood NEFA (Erfle et al., 1971). The liver extracts NEFA at a rate proportional to concentrations present in blood (Reynolds et al., 2003), suggesting that hepatic extraction of NEFA should have been equivalent in feed-restricted cows regardless of infusion type.

Adipose tissue lipolysis could be inhibited as a result of increased hepatic fatty acid oxidation; BHBA has been shown to be antilipolytic in vitro (Rukkwamsuk et al., 1998) and in vivo (Heitmann and Fernandez,
1986) in ruminants. The duration of feed restriction, stage of lactation, and blood sampling frequency likely were not sufficient to test the effect of prolonged negative energy balance and elevated BHBA on adipose tissue lipolysis. Heitmann et al. (1986) reported that a 1-d fast markedly increased plasma NEFA in nonlactating ewes but plasma ketone bodies did not increase until d 3 of fasting. In dairy cows, feed restriction during early lactation increased both NEFA and BHBA (Nielsen et al., 2003). Stage of lactation influences how quickly blood BHBA rises in response to higher blood NEFA during feed restriction due to differences in metabolic fuel utilization and state of hepatic adaptation to negative energy balance (Herdt, 2000; Andersen et al., 2002; Dann and Drackley, 2005).

On d 12, carnitine infusion caused distinct but opposite changes in serum BHBA concentration within each amount of intake. In cows fed ad libitum, serum BHBA increased similarly at $3 \mathrm{~h}$ postfeeding regardless of infusion type, but carnitine infusion decreased serum BHBA at $6 \mathrm{~h}$ postfeeding. Possible explanations include lower alimentary ketogenesis, lower hepatic ketogenesis, greater peripheral BHBA utilization, or a combination of these changes in the CA treatment compared with WA. Interestingly, there were no differences in serum BHBA on d 8 suggesting that adaptation to carnitine infusion altered VFA or NEFA utilization. In the fed ruminant, BHBA and acetoacetate arise from VFA metabolism in ruminal epithelium (Heitmann et al., 1987); the majority of acetoacetate in portal blood is then removed by the liver and converted to BHBA (Heitmann et al., 1986, 1987). Dry matter and nutrient intakes were equivalent between ad libitum-fed groups, thus ruminal VFA production presumably would be similar (Noziere et al., 2000). Carnitine infusion may have altered VFA metabolism in ruminal epithelium and liver resulting in conversion of VFA to compounds other than BHBA.

Carnitine acetyltransferase catalyzes a reversible reaction that condenses acetyl-CoA and carnitine to acetylcarnitine and free CoA; this enzyme also possesses specificity for straight- and branched-chain acyl CoA of $\geq 3$ carbons (Solberg and Bremer, 1970; Clarke and Bieber, 1981). Sheep liver has much greater activity of carnitine acetyltransferase than does rat liver (Snoswell and Henderson, 1970). In rats, carnitine acetyltransferase activity in intestinal mucosa resulted in the formation of significant amounts of acetylcarnitine when exogenous carnitine was supplied in the intestinal lumen (Gudjonsson et al., 1985). In CA cows, supplemental carnitine may have increased carnitine acetyltransferase activity in rumen epithelium, small intestine, or liver, thereby decreasing the availability of precursors for alimentary and hepatic ketogenesis. This 
concept is supported by elevated concentrations of total plasma carnitine and short-chain acylcarnitine in liver and milk of CA cows compared with WA cows (data not shown).

In feed-restricted cows, serum BHBA increased in the $\mathrm{CR}$ treatment but decreased in WR at $6 \mathrm{~h}$ postfeeding on d 12. Similar rates of alimentary ketogenesis would be expected between feed-restricted treatments because DMI was similar (Noziere et al., 2000). Serum NEFA concentration began to increase by $6 \mathrm{~h}$ postfeeding; therefore, hepatic NEFA uptake likely increased as well. Hepatic ketogenesis likely was enhanced in the CR treatment based on rates of in vitro fatty acid oxidation and liver lipid and TG concentrations. Higher serum BHBA and lower liver TG in the CR treatment may represent increased circulating ME during negative energy balance compared with the WR treatment.

Carnitine infusion altered parameters associated with glucose metabolism, such that the CA treatment had higher plasma glucose, lower serum insulin, and lower liver glycogen concentrations than did WA. Previously, continuous abomasal infusion of either 6 or 12 $\mathrm{g} / \mathrm{d}$ of L-carnitine did not affect blood glucose concentration in lactating cows (LaCount et al., 1995, 1996a). The changes in plasma glucose and apparent hepatic glycogenolysis in the CA treatment may have been mediated by decreased insulin concentrations. A possible explanation for lower serum insulin in CA cows is enhanced fatty acid oxidation in the pancreas as a result of carnitine infusion. Glucose-stimulated insulin secretion from pancreatic $\beta$-cells is dependent upon availability of fatty acids (Stein et al., 1996). Furthermore, when CPT-I activity in a rodent $\beta$-cell line was increased, increased fatty acid oxidation resulted in a marked reduction in glucose-stimulated insulin secretion (Herrero et al., 2005). In CA cows, carnitine infusion may have increased fatty acid oxidation in $\beta$-cells, thus decreasing the availability of fatty acids to promote insulin secretion.

Conversely, carnitine infusion may have affected glucose metabolism by altering peripheral glucose metabolism and insulin sensitivity. For example, overexpression of the liver isoform of CPT-I in an insulin-sensitive muscle cell line increased long-chain fatty acid oxidation and insulin-stimulated glucose incorporation into glycogen (Perdomo et al., 2004). Carnitine or acetylcarnitine administration has been shown to stimulate glucose uptake, glucose oxidation, and nonoxidative glucose disposal in healthy and type 2 diabetic humans (see review by Mingrone, 2004). Despite lower liver glycogen concentrations, muscle glycogen concentration was similar between CA and WA. The effect of carnitine supplementation on glucose metabolism in ruminants warrants further investigation.
In feed-restricted cows, insulin concentrations in serum were decreased on d 12 , but carnitine infusion did not affect serum insulin or plasma glucose concentrations. Others have reported acute reductions in blood insulin during feed restriction (Lapierre et al., 1995; Block et al., 2003), whereas Velez and Donkin (2005) did not observe any changes in insulin concentration. Plasma glucose was not affected by feed restriction in the current study, which agrees with observations of others (Lapierre et al., 1995; Velez and Donkin, 2005), yet blood glucose has been shown to decrease as a result of feed restriction in other studies (Block et al., 2003; Nielsen et al., 2003). Differences among studies are likely related to stage of lactation and degree of negative energy balance. Furthermore, in our study feed restriction caused a substantial decline in liver glycogen concentration, which would contribute to maintenance of blood glucose during short-term feed deprivation.

Serum urea N concentration may have been influenced by carryover effects of prior treatments because there were differences among treatments on d 4 even though treatments were not imposed until d 5 . Velez and Donkin (2005) reported that plasma urea $\mathrm{N}$ remained lower in feed-restricted cows even after $10 \mathrm{~d}$ of subsequent realimentation. Carnitine infusion decreased serum urea $\mathrm{N}$ on d 8; previously, ruminal infusion, abomasal infusion, and dietary supplementation of carnitine did not change plasma urea $\mathrm{N}$ in lactating dairy cows (LaCount et al., 1995, 1996b). It is unclear why serum urea $\mathrm{N}$ decreased at $6 \mathrm{~h}$ postfeeding on $\mathrm{d}$ 12 in the CA treatment. In sheep, intravenous carnitine infusion blunted the rise in plasma ammonia $\mathrm{N}$ and urea $\mathrm{N}$ in response to an oral urea load test (Chapa et al., 1998). Carnitine supplementation has been shown to cause metabolic adaptations within liver and muscle that favor fatty acid oxidation and partition of AA away from degradation in salmon (Ji et al., 1996) and swine (Owen et al., 2001). In a similar manner, carnitine infusion into dairy cows fed ad libitum may have altered tissue metabolism of AA.

Hepatic total carnitine concentrations in control cows (WA) were substantially lower than those reported previously (LaCount et al., 1995) but are in close agreement with measurements of Snoswell et al. (1978). Grum et al. (1996) reported that hepatic acid-soluble carnitine increased around calving but returned to prepartum concentrations by wk 3 in lactation. Thus, stage of lactation influences carnitine status and should be considered when comparing our values to those of others. Carnitine infusion increased liver total carnitine concentration in both ad libitum-fed and feed-restricted cows. In a previous experiment, abomasal infusion of carnitine $(\sim 6 \mathrm{~g} / \mathrm{d})$ into ad libitum-fed lactating cows increased total carnitine by $14.6 \%$ compared with con- 
trol cows (LaCount et al., 1995). In the present study, however, abomasal infusion of $20 \mathrm{~g} / \mathrm{d}$ affected total carnitine concentration to a larger extent in the CA treatment compared with WA (a 258\% increase). Feed restriction altered hepatic total carnitine concentration in cows infused with carnitine, but not in unsupplemented cows. In ruminants, catabolic conditions such as fasting, diabetes, and ketosis enhance liver carnitine concentrations (Snoswell and Henderson, 1980); hepatic acid-soluble carnitine concentration in sheep liver increased approximately 4.7-fold during fasting. Cows with low DMI throughout the dry period had increased acid-soluble carnitine in liver $3 \mathrm{wk}$ before calving (Grum et al., 1996). Perhaps the severity or duration of feed restriction or both in our study were insufficient to affect total carnitine concentration in liver of cows not supplemented with exogenous carnitine.

Our hypothesis was that supplemental L-carnitine would lessen hepatic TG accumulation during negative energy balance. In rats, systemic carnitine deficiency induced by trimethylhydraziniumpropionate treatment caused extensive hepatic carnitine depletion and liver lipid accumulation; carnitine feeding almost completely prevented hepatic lipid accumulation in treated rats (Spaniol et al., 2003). In the present study, L-carnitine infusion prevented hepatic lipid and TG accumulation during feed restriction. During the periparturient period, hepatic CPT-I activity (Dann and Drackley, 2005) and mRNA abundance for CPT-I (Loor et al., 2005) were positively associated with serum NEFA concentration. Although hepatic carnitine supply increases around calving (Grum et al., 1996), it is unclear whether endogenous carnitine synthesis is sufficient to maximize CPT-I activity in periparturient dairy cows. Our results indicate that carnitine supplementation might diminish liver TG accumulation around calving.

Rates of palmitate oxidation to $\mathrm{CO}_{2}$ and ASP were substantially lower than those measured in the absence of carnitine in a similar in vitro incubation system (Jesse et al., 1986b; Drackley et al., 1991b). Stage of lactation has a considerable influence upon hepatic fatty acid oxidation, such that liver slices obtained from early lactation cows have higher rates of in vitro palmitate oxidation to ketone bodies than those from midlactation cows (Andersen et al., 2002). Values obtained from the present study are similar to those of Andersen et al. (2002), in which liver slices from midlactation cows were incubated in the absence of carnitine.

Liver slices from cows infused with carnitine had higher rates of palmitate conversion to ASP compared with cows infused with water. Previously, L-carnitine $(1 \mathrm{mM})$ added to incubation media increased $\mathrm{CO}_{2}$, ASP, and total palmitate utilization by liver slices compared with incubations performed without additional carni- tine (Jesse et al., 1986b; Drackley et al., 1991a,b). Knapp (1990) reported that mitochondrial CPT activity in liver tissue from dairy cattle was increased linearly over a range of carnitine concentrations (0 to $400 \mu M)$; our findings indicate that hepatic fatty acid oxidation is responsive to carnitine supply, presumably through modulation of CPT-I activity. Previous research in ruminants has demonstrated that feed deprivation (4 to 7 d) increased palmitate conversion to ASP in sheep liver cells (Lomax et al., 1983) and bovine liver slices (Jesse et al., 1986a; Drackley et al., 1991a) incubated in the absence of media carnitine. However, addition of carnitine to the incubation media resulted in similar conversion rates between fed and fasted animals (Lomax et al., 1983; Jesse et al., 1986a; Drackley et al., 1991a); carnitine addition may have masked the potential effects of elevated tissue carnitine concentrations. Despite differences in hepatic carnitine concentrations between CR and CA treatments, rates of palmitate conversion to ASP were not different. It seems likely that the in vitro incubation system was not highly sensitive to the changes in hepatic carnitine concentrations observed in the present study.

Both carnitine addition to incubation medium and feed deprivation have been shown to significantly decrease the rate of palmitate conversion to EP by bovine liver slices (Drackley et al., 1991a). L-Carnitine infusion decreased the proportion of palmitate converted to EP without interaction with DMI. Although not statistically significant, carnitine exerted a larger effect in the CR treatment than in other treatments. Our results clearly show that although the majority of palmitate was esterified, increasing liver carnitine concentration reduced the proportion of palmitate converted to EP by liver.

Knapp et al. (1992) reported that the majority of radiolabeled alanine was converted to lactate and pyruvate by liver slices obtained from lactating dairy cows; therefore, carnitine may have stimulated flux of alanine through pyruvate carboxylase or pyruvate dehydrogenase and thereby allowed greater $\mathrm{CO}_{2}$ generation from alanine in the CA treatment. In nonruminants, flux of glucogenic substrates through pyruvate carboxylase is stimulated by carnitine supplementation as a result of increased fatty acid oxidation (Ji et al., 1996; Owen et al., 2001). Acetyl-CoA arising from fatty acid oxidation stimulates pyruvate carboxylase while inhibiting pyruvate dehydrogenase, thus diverting pyruvate toward gluconeogenesis rather than oxidation. Chow and Jesse (1992) reported that inhibition of fatty acid oxidation in sheep hepatocytes corresponded to reduced conversion of pyruvate plus lactate to glucose. The interaction between fatty acid oxidation and metabolism of alanine was not tested concurrently in our study because the 
incubation medium did not contain additional fatty acids other than that present in liver tissue. Velez and Donkin (2005) reported that conversion of lactate to glucose was markedly higher in feed-restricted cows in concert with greater pyruvate carboxylase mRNA expression. It is unclear why feed restriction did not similarly affect glucose production from alanine in the present study.

Propionate supply to the liver presumably declined with DMI during feed restriction (Noziere et al., 2000), which supports reduced conversion of propionate to $\mathrm{CO}_{2}$ despite similar conversion to glucose. These findings imply that propionate was directed toward gluconeogenesis at the expense of propionate oxidation during feed restriction. Inhibition of in vitro palmitate oxidation reduced gluconeogenesis from propionate although the mechanism is unknown (Chow and Jesse, 1992). Previously, neither conversion of propionate to glucose nor phosphoenolpyruvate carboxykinase mRNA abundance was affected by feed restriction (Velez and Donkin, 2005). The relative contribution of propionate to glucose is diminished during periods of increased glucose demand, whereas the contribution of alanine and lactate becomes more important (Overton et al., 1999; Reynolds et al., 2003). Consequently, carnitine may benefit hepatic gluconeogenesis from alanine and lactate during the periparturient period, although this hypothesis has not been tested directly.

\section{CONCLUSIONS}

Postruminal infusion of L-carnitine enhances hepatic carnitine concentration and in vitro palmitate oxidation and decreases liver lipid accumulation during experimentally induced negative energy balance. Furthermore, L-carnitine supplementation resulted in greater FCM yield during feed restriction. In cows fed for ad libitum DMI, carnitine infusion appeared to affect glucose and nitrogen metabolism. Further studies addressing the effect of L-carnitine on intermediary metabolism in liver and muscle are justified. Specifically, L-carnitine might be beneficial as a feed additive for prevention of liver TG accumulation during the periparturient period.

\section{ACKNOWLEDGMENTS}

The authors thank the staff at the University of Illinois Dairy Research Unit for assistance with feed preparation. Gratitude is extended to J. Odle and associates at North Carolina State University for assistance with the carnitine assay. The authors thank N. Janovick Guretzky, D. Rincker, E. French, and M. Flach for help with sample collection and analyses.

\section{REFERENCES}

Andersen, J. B., D. G. Mashek, T. Larsen, M. O. Nielsen, and K. L. Ingvartsen. 2002. Effects of hyperinsulinemia under euglycaemic condition on liver fat metabolism in dairy cows in early and midlactation. J. Vet. Med. A 49:65-71.

AOAC. 1995. Official Methods of Analysis. 16th ed. Association of Official Analytical Chemists, Arlington, VA.

Bauman, D. E., D. L. Hard, B. A. Crooker, M. S. Partridge, K. Garrick, L. D. Sandles, H. N. Erb, S. E. Franson, G. F. Hartnell, and R. L. Hintz. 1989. Long-term evaluation of a prolonged-release formulation of $\mathrm{N}$-methionyl bovine somatotropin in lactating dairy cows. J. Dairy Sci. 72:642-651.

Bhuiyan, A. K. M. J., S. Jackson, D. M. Turnbull, A. Aynsley-Green, J. V. Leonard, and K. Bartlett. 1992. The measurement of carnitine and acyl-carnitines: Application to investigation of patients with suspected inherited disorders of mitochondrial fatty acid oxidation. Clin. Chim. Acta 207:185-204.

Block, S. S., R. P. Rhoads, D. E. Bauman, R. A. Ehrhardt, M. A. McGuire, B. A. Crooker, J. M. Griinari, T. R. Mackle, W. J. Weber, M. E. Van Amburgh, and Y. R. Boisclair. 2003. Demonstration of a role of insulin in the regulation of leptin in lactating dairy cows. J. Dairy Sci. 86:3508-3515.

Bobe, G., J. W. Young, and D. C. Beitz. 2004. Pathology, etiology, prevention, and treatment of fatty liver in dairy cows. J. Dairy Sci. 87:3105-3124.

Chapa, A. M., J. M. Fernandez, T. W. White, L. D. Bunting, L. R. Gentry, T. L. Ward, and S. A. Blum. 1998. Influence of intravenous L-carnitine administration in sheep preceding an oral urea drench. J. Anim. Sci. 76:2930-2937.

Chow, J. C., and B. W. Jesse. 1992. Interactions between gluconeogenesis and fatty acid oxidation in isolated sheep hepatocytes. J. Dairy Sci. 75:2142-2148.

Clarke, P. R. H., and L. L. Bieber. 1981. Isolation and purification of mitochondrial carnitine octanoyltransferase activities from beef heart. J. Biol. Chem. 256:9861-9868.

Crocker, C. L. 1967. Rapid determination of urea nitrogen in serum or plasma without deproteinization. Am. J. Med. Technol. 33:361-365.

Dann, H. M., and J. K. Drackley. 2005. Carnitine palmitoyltransferase I in liver of periparturient dairy cows: Effects of prepartum intake, postpartum induction of ketosis, and periparturient disorders. J. Dairy Sci. 88:3851-3859.

Drackley, J. K. 1999. Biology of dairy cows during the transition period: The final frontier? J. Dairy Sci. 82:2259-2273.

Drackley, J. K., D. C. Beitz, and J. W. Young. 1991a. Regulation of in vitro metabolism of palmitate by carnitine and propionate in liver from dairy cows. J. Dairy Sci. 74:3014-3024.

Drackley, J. K., D. C. Beitz, and J. W. Young. 1991b. Regulation of in vitro palmitate oxidation in liver from dairy cows during early lactation. J. Dairy Sci. 74:1884-1892.

Erfle, J. D., L. J. Fisher, and F. Sauer. 1971. Effect of infusion of carnitine and glucose on blood glucose, ketones, and free fatty acids of ketotic cows. J. Dairy Sci. 54:673-680.

Erfle, J. D., F. D. Sauer, and L. J. Fisher. 1974. Interrelationships between milk carnitine and blood and milk components and tissue carnitine in normal and ketotic cows. J. Dairy Sci. 57:671-676.

Fletcher, M. J. 1968. A colorimetric method for estimating serum triglycerides. Clin. Chim. Acta 22:393-397.

Foster, L. B., and R. T. Dunn. 1973. Stable reagents for determination of serum triglycerides by a colorimetric Hantzsch condensation method. Clin. Chem. 19:338-340.

Grum, D. E., J. K. Drackley, R. S. Younker, D. W. LaCount, and J. J. Veenhuizen. 1996. Nutrition during the dry period and hepatic lipid metabolism of periparturient cows. J. Dairy Sci. 79:18501864.

Gudjonsson, H., B. U. Li, A. L. Shug, and W. A. Olsen. 1985. In vivo studies of intestinal carnitine absorption in rats. Gastroenterology 88:1880-1887.

Hara, A., and N. S. Radin. 1978. Lipid extraction of tissue with a low-toxicity solvent. Anal. Biochem. 90:420-426. 
Heitmann, R. N., D. J. Dawes, and S. C. Sensenig. 1987. Hepatic ketogenesis and peripheral ketone body utilization in the ruminant. J. Nutr. 117:1174-1180.

Heitmann, R. N., and J. M. Fernandez. 1986. Autoregulation of alimentary and hepatic ketogenesis in sheep. J. Dairy Sci. 69:1270-1281.

Heitmann, R. N., S. C. Sensenig, C. K. Reynolds, J. M. Fernandez, and D. J. Dawes. 1986. Changes in energy metabolite and regulatory hormone concentrations and net fluxes across splanchnic and peripheral tissues in fed and progressively fasted ewes. J. Nutr. 116:2516-2524.

Herdt, T. H. 2000. Ruminant adaptation to negative energy balance: Influences on the etiology of ketosis and fatty liver. Vet. Clin. North Am. Food Anim. Pract. 16:215-230.

Herrero, L., B. Rubi, D. Sebastian, D. Serra, G. Asins, P. Maechler, M. Prentki, and F. G. Hegardt. 2005. Alteration of the malonyl$\mathrm{CoA} /$ carnitine palmitoyltransferase I interaction in the $\beta$-cell impairs glucose-induced insulin secretion. Diabetes 54:462-471.

Jesse, B. W., R. S. Emery, and J. W. Thomas. 1986a. Aspects of the regulation of long- chain fatty acid oxidation in bovine liver. J. Dairy Sci. 69:2298-2303.

Jesse, B. W., R. S. Emery, and J. W. Thomas. 1986b. Control of bovine hepatic acid oxidation. J. Dairy Sci. 69:2290-2297.

Ji, H., T. M. Bradley, and G. C. Tremblay. 1996. Atlantic salmon (Salmo salar) fed l-carnitine exhibit altered intermediary metabolism and reduced tissue lipid, but no change in growth rate. J. Nutr. 126:1937-1950.

Johnson, M. M., and J. P. Peters. 1993. Technical note: An improved method to quantify nonesterified fatty acids in bovine plasma. J. Anim. Sci. 71:753-756.

Knapp, J. R. 1990. Lactation ketosis: Evaluation of current concepts. $\mathrm{PhD}$ Thesis, University of California, Davis.

Knapp, J. R., H. C. Freetly, B. L. Reis, C. C. Calvert, and R. L. Baldwin. 1992. Effect of somatotropin and substrates on patterns of liver metabolism in lactating dairy cattle. J. Dairy Sci. 75:1025-1035.

LaCount, D. W., J. K. Drackley, and D. J. Weigel. 1995. Responses of dairy cows during early lactation to ruminal or abomasal administration of L-carnitine. J. Dairy Sci. 78:1824-1836.

LaCount, D. W., L. S. Emmert, and J. K. Drackley. 1996a. Dose response of dairy cows to abomasal administration of four amounts of L-carnitine. J. Dairy Sci. 79:591-602.

LaCount, D. W., L. D. Ruppert, and J. K. Drackley. 1996b. Ruminal degradation and dose response of dairy cows to dietary L-carnitine. J. Dairy Sci. 79:260-269

Lapierre, H., G. Pelletier, T. Abribat, K. Fournier, P. Gaudreau, P. Brazeau, and D. Petitclerc. 1995. The effect of feed intake and growth hormone-releasing factor on lactating dairy cows. J. Dairy Sci. 78:804-815.

Lin, X., and J. Odle. 2003. Changes in kinetics of carnitine palmitoyltransferase in liver and skeletal muscle of dogs (Canis familiaris) throughout growth and development. J. Nutr. 133:1113-1119.

Litherland, N. B., S. Thire, A. D. Beaulieu, C. K. Reynolds, J. A. Benson, and J. K. Drackley. 2005. Dry matter intake is decreased more by abomasal infusion of unsaturated free fatty acids than by unsaturated triglycerides. J. Dairy Sci. 88:632-643.

Littell, R. C., P. R. Henry, and C. B. Ammerman. 1998. Statistical analysis of repeated measures data using SAS procedures. J. Anim. Sci. 76:1216-1231.

Lo, S., J. C. Russell, and A. W. Taylor. 1970. Determination of glycogen in small tissue samples. J. Appl. Physiol. 28:234-236.

Lomax, M. A., I. A. Donaldson, and C. I. Pogson. 1983. The control of fatty acid metabolism in liver cells from fed and starved sheep. Biochem. J. 214:553-560.

Loor, J. J., H. M. Dann, R. E. Everts, R. Oliveira, C. A. Green, N. A. Janovick Guretzky, S. L. Rodriguez-Zas, H. A. Lewin, and J. K. Drackley. 2005. Temporal gene expression profiling of liver from periparturient dairy cows reveals complex adaptive mechanisms in hepatic function. Physiol. Genomics 23:217-226.

McGarry, J. D., and N. F. Brown. 1997. The mitochondrial carnitine palmitoyltransferase system: From concept to molecular analysis. Eur. J. Biochem. 244:1-14.
McGarry, J. D., and D. W. Foster. 1976. An improved and simplified radioisotopic assay for the determination of free and esterified carnitine. J. Lipid Res. 17:277-281.

Mills, S. E., L. E. Armentano, R. W. Russell, and J. W. Young. 1981. Rapid and specific isolation of radioactive glucose from biological samples. J. Dairy Sci. 64:1719-1723.

Mingrone, G. 2004. Carnitine in type 2 diabetes. Ann. N.Y. Acad. Sci. 1033:99-107.

National Research Council. 2001. Nutrient Requirements of Dairy Cattle. 7th rev. ed. Natl. Acad. Sci., Washington, DC.

Nielsen, N. I., K. L. Ingvartsen, and T. Larsen. 2003. Diurnal variation and the effect of feed restriction on plasma and milk metabolites in TMR-fed dairy cows. J. Vet. Med. A. 50:88-97.

Noziere, P., D. Remond, L. Bernard, and M. Doreau. 2000. Effect of underfeeding on metabolism of portal-drained viscera in ewes. Br. J. Nutr. 84:821-828.

Overton, T. R., J. K. Drackley, C. J. Ottemann-Abbamonte, A. D. Beaulieu, L. S. Emmert, and J. H. Clark. 1999. Substrate utilization for hepatic gluconeogenesis is altered by increased glucose demand in ruminants. J. Anim. Sci. 77:1940-1951.

Owen, K. Q., H. Ji, C. V. Maxwell, J. L. Nelssen, R. D. Goodband, M. D. Tokach, G. C. Tremblay, and S. I. Koo. 2001. Dietary Lcarnitine suppresses mitochondrial branched-chain keto acid dehydrogenase activity and enhances protein accretion and carcass characteristics of swine. J. Anim. Sci. 79:3104-3112.

Perdomo, G., S. R. Commerford, A. T. Richard, S. H. Adams, B. E. Corkey, R. M. O'Doherty, and N. F. Brown. 2004. Increased $\beta$ oxidation in muscle cells enhances insulin-stimulated glucose metabolism and protects against fatty acid-induced insulin resistance despite intramyocellular lipid accumulation. J. Biol. Chem. 279:27177-27186.

Peterson, J. I., and D. S. Young. 1968. Evaluation of the hexokinase/ glucose-6-phosphate dehydrogenase method of determination of glucose in urine. Anal. Biochem. 23:301-316.

Piepenbrink, M. S., A. L. Marr, M. R. Waldron, W. R. Butler, T. R. Overton, M. Vazquez-Anon, and M. D. Holt. 2004. Feeding 2hydroxy-4-(methylthio)-butanoic acid to periparturient dairy cows improves milk production but not hepatic metabolism. J. Dairy Sci. 87:1071-1084.

Piepenbrink, M. S., and T. R. Overton. 2003. Liver metabolism and production of cows fed increasing amounts of rumen-protected choline during the periparturient period. J. Dairy Sci. 86:17221733.

Rebouche, C. J., and H. Seim. 1998. Carnitine metabolism and its regulation in microorganisms and mammals. Annu. Rev. Nutr. 18:39-61.

Reynolds, C. K., P. C. Aikman, B. Lupoli, D. J. Humphries, and D. E. Beever. 2003. Splanchnic metabolism of dairy cows during the transition from late gestation through early lactation. J. Dairy Sci. 86:1201-1217.

Rukkwamsuk, T., T. Wensing, and M. J. H. Geelen. 1998. Effect of overfeeding during the dry period on regulation of adipose tissue metabolism in dairy cows during the periparturient period. J. Dairy Sci. 81:2904-2911.

Snoswell, A. M., N. D. Costa, J. G. McLean, G. D. Baird, M. A. Lomax, and H. W. Symonds. 1978. Interrelationships between acetylation and disposal of acetyl groups in the livers of dairy cows. J. Dairy Res. 45:331-338.

Snoswell, A. M., and G. D. Henderson. 1970. Aspects of carnitine ester metabolism in sheep liver. Biochem. J. 119:59-65.

Snoswell, A. M., and G. D. Henderson. 1980. Carnitine and metabolism in ruminant animals. Page 191 in Carnitine Biosynthesis, Metabolism, and Functions. R. A. Frenkel and J. D. McGarry, ed. Academic Press, Inc., New York, NY.

Solberg, H. E., and J. Bremer. 1970. Formation of branched chain acylcarnitines in mitochondria. Biochim. Biophys. Acta 222:372-380.

Spaniol, M., P. Kaufmann, K. Beier, J. Wuthrick, M. Torok, H. Scharnagl, W. Marz, and S. Krahenbuhl. 2003. Mechanisms of liver steatosis in rats with systemic carnitine deficiency due to treatment with trimethylhydraziniumpropionate. J. Lipid Res. 44:144-153. 
Stein, D. T., V. Esser, B. E. Stevenson, K. E. Lane, J. H. Whiteside, M. B. Daniels, S. Chen, and J. D. McGarry. 1996. Essentiality of circulating fatty acids for glucose-stimulated insulin secretion in the fasted rat. J. Clin. Invest. 97:2728-2735.

Studer, V. A., R. R. Grummer, S. J. Bertics, and C. K. Reynolds. 1993. Effect of prepartum propylene glycol administration on periparturient fatty liver in dairy cows. J. Dairy Sci. 76:29312939.

Vaz, F. M., and R. J. A. Wanders. 2002. Carnitine biosynthesis in mammals. Biochem. J. 361:417-429.
Veenhuizen, J. J., J. K. Drackley, M. J. Richard, T. P. Sanderson, L. D. Miller, and J. W. Young. 1991. Metabolic changes in blood and liver during development and early treatment of experimental fatty liver and ketosis in cows. J. Dairy Sci. 74:4238-4253.

Velez, J. C., and S. S. Donkin. 2005. Feed restriction induces pyruvate carboxylase but not phosphoenolpyruvate carboxykinase in dairy cows. J. Dairy Sci. 88:2938-2948.

Williamson, D. H., and J. Mellanby. 1974. D-(-)-3-hydroxybutyrate. Pages 1836-1840 in Methods of Enzymatic Analysis. Vol. 4. H. U. Bergmeyer, ed. Academic Press, London, UK. 